1) консультанта, передача информации, необходимой для принятия решения в той или иной проблемной ситуации;

2) организатора, активизация всех видов ресурсов для устранения трудной жизненной ситуации клиента;

3) социального адвоката, защита, посредничество, переговоры в интересах клиента в конфликтных ситуациях;

4) активатора социальных изменений повышающих уровень качества жизни населения в целом и отдельно взятого человека;

5) предпринимателя в сфере социального бизнеса.

Качество и эффективность управления и предпринимательства в социальной работе зависит от уровня компетентности специалиста социальной работы, понимая полифункциональность его деятельности.

Процесс подготовки бакалавров по социальной работе к полифункциональной деятельности требует теоретического анализа всего спектра функций, обеспечивающих эффективность управления и предпринимательства в социальной сфере, только тогда специалист будет готов к встрече с социально-профессиональными инновациями будущего, так как будет владеть востребованной обществом трансфессией.

$$
* * *
$$

1. Зеер, Э. Ф. Психолого-педагогическая платформа формирования транспрофессионализма педагога профессионального образования / Э. Ф. Зеер // Профессиональное образование. Столица. - 2017. - № 6. - С. 5-9.

2. Зеер Э. Ф. Методологические ориентиры развития транспрофессионализма педагогов профессионального образования / Э. Ф. Зеер, Э. Э. Сыманюк // Образование и наука. 2017. Т. 19, № 8. С. 9-28.

3. Федеральный государственный образовательный стандарт высшего образования. Бакалавриат. Направление подготовки. Социальная работа. [Электронный ресурс], режим доступа http://www.consultant.ru/document/cons_doc_LAW_194219/

\title{
Основина Т.Ю. \\ Специфика использования технологии мастер-класса со студентами профиля «Управление и предпринимательство в социальной сфере» как методической формы реализации практических занятий по курсу «Маркетинг социальных услуг»
}

Нижнетагильский государственный сочиально-педагогический институт (филиал) ФГАОУ ВПО «Российский государственный профессионально-педагогический университет»

doi: 10.18411/trnio-10-2021-13

(Россия, Нижний Тагил)

\section{Аннотация}

Проанализирована специфика и возможность использования технологии мастеркласса как методической формы реализации практических занятий по курсу «Маркетинг социальных услуг».

Ключевые слова: мастер-класс, технология мастер-класса, мастер, практикоориентированная подготовка студентов, маркетинг социальных услуг.

\section{Abstract}

The article analyzes the specification and the possibility of using the technology of the master class as a methodological form of implementation of practical classes in the course "Marketing of social services".

Keywords: master class, master class technology, master, practice-oriented training of students, marketing of social services.

В современной системе образования в области социальной работы ведущим является практико-ориентированное обучение, что позволяет спроектировать учебный процесс как 
систему с обратной связью, с циклическим переходом от теории к практике и обратно, увязать теоретические и практические учебные задачи друг с другом, а также с реальными производственными ситуациями, благодаря чему учащиеся получают знания, имеющие определенную практическую ориентацию.

Достижение максимально полезного эффекта от реализации этого подхода при обучении возможно при учете основных дидактических условий:

- деятельностная подача содержания обучения управленческопредпринимательской деятельности;

- систематическое и последовательное рассмотрение прикладного аспекта маркетинговых знаний.

Реализация практико-ориентированного подхода к обучению в процессе преподавания курса «Маркетинг социальных услуг», повышает уровень готовности учащихся к управленческо-предпринимательской деятельности и практическому взаимодействию с объектами социальной сферы. Эта задача может быть решена путем:

- изменения методики работы с содержанием учебных предметов за счет отработки принципов практико-ориентированного образования и реализации практико-ориентированных методов в различных видах образовательных сред;

- создания такой образовательной среды, которая позволяла бы сознанию студента развиваться на основе единства теоретических знаний и практических умений посредством расширения личностного профессионального опыта;

- разработки принципов конструирования образовательной среды за счет разнообразных практик, которые составляют базу, социального образования.

Одним из эффективных видов практик является методика проведения мастер классов. Мастер-класс - это интерактивный метод обучения и обмена опытом, слияние формата тренинга и конференции или семинара для отработки практических навыков по различным методикам и технологиям с целью повышения профессионального уровня и обмена передовым опытом, расширения кругозора и приобщения к новейшим областям знания.

Мастер-класс соединяет теорию и практику в обучении, создает устойчивый познавательный интерес учащихся к учебно-воспитательному процессу, происходит усвоение учебного материала большинством учащихся, формирует творческие умения учащихся, обеспечивает учащихся методологией, позволяющей самостоятельно применять накопленные знания и получать новые знания в процессе собственной деятельности.

Мастер-класс - это особая форма учебного занятия, которая основана на «практических» действиях показа и демонстрации творческого решения определенной познавательной и проблемной педагогической задачи. В технологии проведения мастеркласса главное - передача тревиальным способом информации, а трансляция эффективных способов деятельности:

$$
\begin{array}{ll}
\text { - прием, } \\
\text { - } \\
\text { метод, } \\
\text { — } \\
\text { методика, } \\
\text { технология. }
\end{array}
$$

Сам процесс изучения маркетинга социальных услуг носит творческоисследовательский характер, так как является управленческой практикой, относительно новой для России и находится в процессе своего становления. В ходе обучения возбуждаются и развиваются внутренние мотивы учения, реализуется аналитическая деятельность учащихся, формируются прикладные маркетинговые знания и навыки, создаются условия для реализации познавательных поисков, для самовыражения и творчества, особенно это проявляется при изучении раздела «Социальная реклама». 
Тематика мастер-классов при изучении «Маркетинга социальных услуг» может включает в себя:

- представление актуальных маркетинговых технологий технологий,

современные приемы использования маркетинговых технологий при решении социальных проблем как общества в целом, так и отдельно взятого человека,

- авторские методы и наработки компаний в применении маркетинговых технологий на практике и др.

Технологически мастер-класс это сложный процесс с определенными требованиями к его организации и проведению. В ходе мастер-класса участники:

- изучают маркетинговые материалы, документы или разработки по теме мастер-класса;

- участвуют копируя мастера или моделируя свое поведение в предложенной социальной ситуации;

- анализируют, обсуждают полученные результаты;

- задают вопросы, получают консультации;

- высказывают свои предложения по решению социальных проблем.

Подбор заданий и распределение ролей при работе на мастер-классе позволяет учитывать индивидуальные особенности студентов. Так обеспечивается возможность сочетать развитие познавательных способностей студентов с приобретением навыков маркетинга в социальной сфере при обучении в вузе.

В задачи мастер-класса входит:

- передача мастером своего опыта путем прямого и комментированного представления последовательности маркетинговых действий и методов деятельности, например по проведению маркетингового исследования целевого сегмента клиентов учреждений социальной сферы;

- совместная отработка приемов мастера по решению поставленной в программе мастер-класса социальной проблемы, это могут быть профессиональные советы по разработке рекламного продукта;

- оценка собственного уровня профессионального мастерства студентами и их уровня мастером;

- содействие студентам, участвовавшим в мастер-классе в определении вектора саморазвития и формировании индивидуальной профессиональной перспективы.

Реализация представленных задач мастер-класса выводит учащегося на уровень компетентного поступка. Такое обучение уже не будет подготовкой к будущей профессиональной деятельности, а станет осознанным профессиональным действием в настоящем времени.

Мастер-класс является не типовым способом организации профессиональной подготовки, поэтому наиболее эффективен в составе малой группы, но в условиях высшей школы приемлем в студенческой группе. Задача мастера в процессе проведения мастеркласса - передать свой опыт так, чтобы студенты захотели его принять. Действия мастера должны отличаться креативом, глубоким знанием темы, владением маркетинговой технологией. Роль мастера - это консультант, но при этом он работает вместе со всеми, создает атмосферу открытости, доброжелательности, сотворчества.

Исходя из данных рекомендаций на позицию мастера может быть приглашен специалист социальной работы из учреждений социальной сферы, в чьи должностные обязанности входит маркетинговая деятельность в сфере социальных услуг, или специалист маркетингового подразделения организации, имеющей социальную инфраструктуру, реализующую и социальные услуги в том числе, или представитель НКО, занимающийся маркетинговыми технологиями (социальная реклама, спонсоринг, фондрайзинг). В роли 
мастера может быть и педагог, если он является практикующим или стажирующимся специалистом в области маркетинга.

Цель дисциплины «Маркетинг социальных услуг» является формирование системных знаний о содержании и методах маркетинга, овладение технологиями и навыками маркетинговых действий в социальной сфере. Процесс изучения дисциплины направлен на развитие с компетенций, которые эффективнее будут формироваться с помощью мастер-класса.

- УК1. Способен осуществлять поиск, критический анализ и синтез информации, применять системный подход для решения поставленных задач.

- ОПК-2. Способен описывать социальные явления и процессы на основе анализа и обобщения профессиональной информации, научных теорий, концепций и актуальных подходов.

- ПК-4. Способностью к обеспечению комплексного взаимодействия с другими специалистами, учреждениями, организациями и сообществами по оказанию помощи в преодолении трудной жизненной ситуации гражданина.

Исходя из этого мастер-класс может иметь тематику:

- Маркетинговое исследование.

- Маркетинговые мероприятия.

- Реклама.

- Виды маркетинга. Специфика маркетинговых действий.

Алгоритм технологии мастер-класса может поделен на этапы:

1. презентация маркетингового действия мастером;

2. представление системы эффективных приемов работы, которые мастер будет демонстрировать;

3. проведение деловой игры для отработки приемов;

4. моделирование и презентация собственного приема в рамках маркетинговой технологии;

5. рефлексия: мастер совместно со студентами проводит обсуждение авторских моделей и дискуссия по результатам совместной деятельности.

$$
* * *
$$

1. Игротехнические формы образовательных методик в социально-профессиональном образовании Основина Т.Ю. Вопросы педагогики. 2020. № 8-1. С. 75-78.

2. Креативная практика как процесс формирования креативного потенциала студентов в условиях высшей школы. Основина Т.Ю. Вопросы педагогики. 2020. № 7-2. С. 118-120.

3. Федеральный государственный образовательный стандарт высшего образования. Бакалавриат. Направление подготовки. Социальная работа. [Электронный ресурс], режим доступа http://www.consultant.ru/document/cons_doc_LAW_194219/

\section{Островская И.Э. \\ Развитие непрерывного образования современного педагога высшего образования}

ФГБОУ ВО «Приморская государственная сельскохозяйственная академия» (Россия, Уссурийск)

doi: 10.18411/trnio-10-2021-14

\section{Аннотация}

Новые качества жизни становятся условиями развития образования, требуют обновления целей и предъявлят к образованию новоявленные притязания. Одним из таких притязаний является способность человека перманентно учиться - искать и находить знания, применять их на практике, не удовлетворяться достигнутым, постоянно обновлять, приводить в систему и ревизовать собственные знания. Данная способность становится способом адаптации и защиты от постоянно возникающих угроз и одновременно 